\title{
Arbuscular mycorrhizal fungi enhance photosynthesis, water use efficiency, and growth of frankincense seedlings under pulsed water availability conditions
}

\author{
Emiru Birhane • Frank J. Sterck • Masresha Fetene • \\ Frans Bongers · Thomas W. Kuyper
}

Received: 5 August 2011 / Accepted: 11 January 2012 / Published online: 28 January 2012

(C) The Author(s) 2012. This article is published with open access at Springerlink.com

\begin{abstract}
Under drought conditions, arbuscular mycorrhizal (AM) fungi alter water relationships of plants and improve their resistance to drought. In a factorial greenhouse experiment, we tested the effects of the AM symbiosis and precipitation regime on the performance (growth, gas exchange, nutrient status and mycorrhizal responsiveness) of Boswellia papyrifera seedlings. A continuous precipitation regime was imitated by continuous watering of plants to field capacity every other day during 4 months, and irregular precipitation by pulsed watering of plants where watering was switched every 15 days during these 4 months, with 15 days of watering followed by 15 days without watering. There were significantly higher levels of AM colonization under irregular precipitation regime than under continuous precipitation. Mycorrhizal seedlings had
\end{abstract}

Communicated by Frederick Meinzer.

Electronic supplementary material The online version of this article (doi:10.1007/s00442-012-2258-3) contains supplementary material, which is available to authorized users.

E. Birhane · F. J. Sterck $(\bowtie) \cdot$ F. Bongers

Forest Ecology and Forest Management Group,

Wageningen University, P.O. Box 47,

6700 AA Wageningen, The Netherlands

e-mail: Frank.Sterck@wur.nl

E. Birhane

Mekelle University, P.O. Box 231, Mekelle, Ethiopia

E. Birhane $\cdot$ T. W. Kuyper

Department of Soil Quality, Wageningen University,

P.O. Box 47, 6700 AA Wageningen, The Netherlands

\section{Fetene}

Addis Ababa University, P.O. Box 1176,

Addis Ababa, Ethiopia higher biomass than control seedlings. Stomatal conductance and phosphorus mass fraction in shoot and root were also significantly higher for mycorrhizal seedlings. Mycorrhizal seedlings under irregular watering had the highest biomass. Both a larger leaf area and higher assimilation rates contributed to higher biomass. Under irregular watering, the water use efficiency increased in non-mycorrhizal seedlings through a reduction in transpiration, while in mycorrhizal seedlings irregular watering increased transpiration. Because assimilation rates increased even more, mycorrhizal seedlings achieved an even higher water use efficiency. Boswellia seedlings allocated almost all carbon to the storage root. Boswellia seedlings had higher mass fractions of $\mathrm{N}, \mathrm{P}$, and $\mathrm{K}$ in roots than in shoots. Irregular precipitation conditions apparently benefit Boswellia seedlings when they are mycorrhizal.

Keywords Water pulse $\cdot$ AM fungi $\cdot$ Boswellia papyrifera $\cdot$ Precipitation $\cdot$ Seedling

\section{Introduction}

Prolonged seasonal drought severely affects regeneration of trees and survival of their seedlings and saplings in drylands (Gindaba et al. 2005; Gebrehiwot et al. 2005; Gebrekirstos et al. 2006). Arbuscular mycorrhizal (AM) fungi can alter water relationships of plants such that they improve the resistance of plants to drought (Augé 2001; Smith and Read 2008; Lambers et al. 2008; Ruiz-Lozano and Aroca 2010; Apple 2010). Various mechanisms have been proposed through which the AM symbiosis improves drought resistance. These underlying mechanisms are partly nutritional (enhanced uptake of $\mathrm{P}$, but also of $\mathrm{K}, \mathrm{N}, \mathrm{Ca}, \mathrm{Mg}, \mathrm{Zn}$, and $\mathrm{Cu})$ and partly non-nutritional. Non-nutritional mechanisms 
include hormonal effects (through abscisic acid) due to mycorrhizal colonization, improved soil-hyphal contact (especially important during soil drying), more effective scavenging for water in micropores, direct water uptake by hyphae, and increased photosynthesis through sink stimulation (Augé 2001; Kaschuk et al. 2009; Smith et al. 2010). Augé (2004) subsequently demonstrated that the mycorrhizal network also affects moisture retention properties of soils, such that non-mycorrhizal plants growing in a mycorrhizal soil also had increased stomatal conductance. As Augé (2001) noted, field effects of AM fungi on increased plant performance under drought are usually a combination of nutritional and non-nutritional effects. While mycorrhizal plants thus acquire more water and nutrients, they inevitably transpire more water, too. However, several studies have also reported a mycorrhiza-induced increase in plant water use efficiency (WUE) (Kaya et al. 2003; Ruiz-Lozano and Aroca 2010).

In this study, we focused on the role of the AM symbiosis in the water relationships of the frankincense tree Boswellia papyrifera (Burseraceae-henceforth Boswellia). Boswellia is found in Acacia-Commiphora woodlands and wooded grasslands of dry areas in the Horn of Africa at $500-1,500 \mathrm{~m}$ altitude, with average temperatures of $20-25^{\circ} \mathrm{C}$, annual rainfall below $900 \mathrm{~mm}$, and with a wet growing season of 2-4 months (Bekele 2007; Ogbazgi et al. 2006). In these dry environments, high temperatures and erratic moisture inputs impose a pulsed pattern of water and soil nutrient availability between the dry season and wet growing season, but also between wetter and drier periods during the growth season (Collins et al. 2008; Schwinning and Sala 2004; Chesson et al. 2004). During the long dry season, which usually lasts for 8-10 months, seedlings naturally die-back above-ground but survive below-ground (Gindaba et al. 2004). Seedlings produce new aboveground shoots during the wet growing season, but may then still face water stress because of irregular rains. The precipitation regime thus involves both a long dry period and short term periods of water stress, and may select for specific plant morphological and physiological adaptations (Schwinning and Ehleringer 2001; Schwinning and Sala 2004). Boswellia is ecologically adapted to such pulsed growth conditions (Gebrehiwot et al. 2005; Ogbazgi et al. 2006; Abiyu et al. 2010). In an earlier study, we concluded that the AM symbiosis contributes to this adaptation and hence makes a major contribution to establishment, growth, and survival of this woodland species under the prevailing harsh climate (Birhane et al. 2010). Root colonization levels were higher during the dry than during the wet season. As the plants were leafless during the dry period (although Boswellia possesses photosynthetic stems), it seems plausible that carbon gain by the plant and carbon expenditure by the fungus are temporally disconnected. This temporal disconnect could be a specific adaptation to pulsed resource availability (Birhane et al. 2010). A temporal disconnect as a strategy of drought tolerance has been described before in the vernal herb Erythronium americanum (Lapointe and Molard 1997; Lapointe 2001). Querejeta et al. (2007b) described how hydraulic lift by woody roots of mycorrhizal trees resulted in water exudation from roots that allowed mycorrhizal fungal hyphae to remain active during periods of severe soil drying. In this study, we tested the effect of the AM symbiosis in combination with water availability (pulsed or not) for three Boswellia seedling age groups to determine seedling performance (carbon and nutrient acquisition, and water use). We hypothesized that:

- Mycorrhizal plants are larger than non-mycorrhizal plants;

- Mycorrhizal Boswellia seedlings have higher gas exchange, leaf water potential, and relative water content than seedlings without $\mathrm{AM}$;

- Mycorrhizal benefit is larger under water-pulsed conditions (irregular water supply) than under conditions of regular watering;

- Higher biomass in mycorrhizal seedlings under waterpulsed conditions is a result of higher assimilation rate and water use efficiency.

\section{Materials and methods}

A greenhouse experiment with Boswellia seedlings was conducted in northern Ethiopia at the Illala plant tissue culture greenhouse, Tigray Agricultural Research Institute, Mekelle $\left(13^{\circ} 29^{\prime} \mathrm{N}, 39^{\circ} 28^{\prime} \mathrm{E}\right.$; altitude 2,000 m a.s.l.) from 1 June 2008 to 30 October 2009. Mean daily temperature of the greenhouse was $25^{\circ} \mathrm{C}$ during the day and $22^{\circ} \mathrm{C}$ during the night with mean daily average relative humidity of $51 \%$ for the study period.

Seedling preparation and selection

Seeds from adult Boswellia trees from the dry deciduous woodlands in Abergelle, northern Ethiopia, were collected in March 2007. Healthy trees with a single stem and with uniform seed setting were selected for seed collection. Seeds were directly picked by hand from tree branches either by climbing or standing on the ground depending on tree height. Seeds were soaked in cold water for $12 \mathrm{~h}$ to accelerate germination. Germination took place in plastic trays filled with autoclaved pure river sand under greenhouse conditions. All seeds germinated within 5-10 days. A total of 160 germinated seeds were individually transplanted to plastic pots, $8 \mathrm{~cm}$ diameter and $15 \mathrm{~cm}$ high. Potted seedlings were placed on metal mesh benches and were watered regularly using micro-sprinkler irrigation every 
other day to field capacity until the plants were ready for the experiment. Dimethoate was sprayed to ward off ants and aphids which were observed on leaves. Of the 144 seedlings of uniform size, 12 seedlings were harvested after 1 month. At the same time, half of the remaining 132 seedlings were inoculated and all 132 were transplanted to larger perforated 20-1 plastic containers. A single seedling was planted per container, each container being filled with $15 \mathrm{~kg}$ autoclaved soil.

\section{Preparation of inoculum of AM fungi}

Spores of AM fungi were collected during the dry season from the rhizosphere of the same Boswellia trees by the wet sieving and decanting method (Brundrett et al. 1996). Most spores belonged to the genus Glomus (Birhane et al. 2010) and these were not further identified to species. Spore cultures were maintained on plants of Sorghum bicolor. The fungal inoculum added to the seedlings consisted of a mixture of soil, spores, and root fragments, produced from the rhizosphere of pre-colonized Sorghum bicolor plants. About $50 \mathrm{~g}$ of fungal inoculum was added near the roots of each seedling at the center of the pot. In order to mimic the natural growth conditions for the seedlings, the potting soil was also excavated from Abergelle, in a similar habitat where Boswellia trees naturally grow. Before inoculation, the potting soils were sieved and sterilized by an autoclave at $121^{\circ} \mathrm{C}$ for $2 \mathrm{~h}$. Control seedlings were planted in sterilized soils.

\section{Experimental design and treatments}

The experiment consisted of a three-factorial design: AM fungi (present or absent), water supply (continuous watering vs. pulsed watering), and seedling age (seedlings harvested after 4, 12, and 16 months). We mimicked seasonality by supplying water for 4 months followed by 8 months without any water. During that period, seedlings died back above-ground. After 1 year, we mimicked the second rainy season by supplying water for another 4 months. Seedlings harvested after 4 months were given water to field capacity; seedlings grown for 12 months were given water for 4 months, kept without water for 8 months, and harvested after re-emergence; and seedlings grown for 16 months were given water during the two rainy seasons, 4 months each, and left without water for 8 months. In order to simulate dry spells during the rainy season, we supplied the seedlings either with water for 15 days followed by 15 days of drought (water pulse, SP) or every other day (continuous water, WC). When watered, pots were filled to field capacity, based on their mass. The treatment units were arranged on greenhouse benches in a completely randomized design. There were 11 replications which gave a total of 144 seedlings (since 12 seedlings were initially harvested, 132 seedlings were actually planted and exposed to the actual treatments).

Measurement of seedling traits

We harvested seedlings four times (at the start of the experiment, and after 4,12 , and 16 months). We determined plant size, biomass, and growth rate. Total shoot length (plant height) was measured using a graduated meter, and root collar diameter was measured using a digital caliper. The number of fully developed leaves was assessed for each seedling. Leaf surface area was measured using AM 100 leaf area meter (ADC Bioscientific). Harvested seedlings were divided into coarse roots, fine roots, stems, and leaves and their dry mass was determined after oven-drying at $80^{\circ} \mathrm{C}$ until constant weight was achieved. We then calculated leaf, stem, fine root, and coarse root mass fractions (dry mass.dry plant mass ${ }^{-1}, \mathrm{~g} \mathrm{~g}^{-1}$ ], leaf area ratio [leaf area $\left(\mathrm{cm}^{2}\right)$ plant dry mass $^{-1}\left(\mathrm{~g}^{-1}\right)$ ], specific leaf area [leaf area $\left(\mathrm{cm}^{2}\right) \cdot$ leaf dry mass $^{-1}\left(\mathrm{~g}^{-1}\right)$ ], and root:shoot ratio (Hunt 1990). Total root length was estimated using the grid line intersect method (Tennant 1975). In addition, specific root length (root length.dry root mass ${ }^{-1}, \mathrm{~mm} \mathrm{~g}^{-1}$ ), root length per unit plant mass and root length per unit leaf area were calculated as root traits. The number and length of primary roots per plant were assessed and determined. Relative growth rate was calculated according to Hunt (1990) and Chiariello et al. (1989).

Plant nutrient analysis

Mineral status of the plants was determined by conducting shoot and root tissue elemental analysis. After sun-drying, shoot and root samples were oven-dried at $80^{\circ} \mathrm{C}$ for $48 \mathrm{~h}$. Samples were then wet-digested and analyzed for N, P, and $\mathrm{K}$. Total $\mathrm{N}$ was determined using the standard Kjeldahl method, $\mathrm{P}$ colorimetrically by spectrophotometer, and $\mathrm{K}$ by flame photometry (Anderson and Ingram 1993).

\section{Mycorrhizal colonization}

Mycorrhizal colonization was assessed using the grid line intersection method (Giovannetti and Mosse 1980). Subsamples of (non-suberized) roots were collected, cleared with $10 \% \mathrm{KOH}$, and stained with $0.01 \%$ trypan blue in lactoglycerol (Brundrett et al. 1996). Roots were then divided into $1 \mathrm{~cm}$ pieces and mounted lengthwise on a microscope slide. Eleven slides per treatment per harvest containing nine root pieces per slide were examined by making three microscope observations (top, middle and bottom) per $1 \mathrm{~cm}$ root piece at $\times 400$ magnification $(n=891)$. Colonization was expressed as percentage of the root length colonized. Total fractional colonization and those of arbuscules, vesicles, and internal hyphae in the root cortex were recorded. 
Mycorrhizal responsiveness was expressed as the ratio of total dry weight of mycorrhizal plants and non-mycorrhizal plants. Drought response index was calculated as the ratio of total dry weight of plants exposed to water supplied in pulses (SP) to plants under well-watered conditions (WC).

Gas exchange measurements

Gas exchange was measured for the 16-month-old seedlings. Measurements were made between 0900 and 1200 hours from five mature fully expanded leaves two times per leaf $(n=11)$ under full sunlight using a LCP-002 portable photosynthesis system (LC Pro; ADC Bioscientific). Measurements included net photosynthesis rate, stomatal conductance, transpiration rate, and dark respiration rate. Photosynthetic water use efficiency was calculated as the ratio between the photosynthesis rate and transpiration rate. Predawn (0300-0600 hours) and midday (12001400 hours) leaf water pressure potential were measured using a pressure chamber apparatus (Scholander et al. 1965) using well-expanded leaves. Relative water content of leaves was measured according to Koide et al. (1989). Water pressure potential and relative water content were determined twice in the course of the experiment.

Statistical analysis

A three-way analysis of variance (ANOVA) was used to test for significant sources of variation in differences in seedling size, biomass and nutrient levels; a two-way ANOVA was applied for root colonization (water pulse; seedling age) and gas exchange (water pulse, mycorrhiza). Repeated-measures ANOVA was used to analyze treatment effects on predawn and midday relative water content and leaf water potential of seedlings. Because of the large number of parameters, a sequential Bonferroni correction was applied at $P<\alpha /$ $(1+k-i)$ significance level, with $\alpha=0.05$; $k$ is the number of parameters (40); $i$ is the sequential value after sorting in ascending order, when $F$ test from ANOVA was significant. Gabriel post hoc test for unequal sample size and LSD for main effect comparison were performed. In order to meet the assumptions of normal distribution and homogeneity of variances, data on leaf number were arcsine square root-transformed; data on root collar diameter, shoot length, stem dry mass, coarse root dry mass, fine root dry mass, shoot dry mass, total plant dry mass, leaf relative growth rate, root length per leaf area, net photosynthetic rate, and dark respiration rate were log-transformed before statistical analysis. Treatment effects were statistically analyzed using SPSS (PASW statistics 17) software.

\section{Results}

Plant size and growth

Most plant traits were significantly affected by seedling age, and some (especially root biomass) by mycorrhiza, while water pulse was in most cases not a significant source of variation. The interaction water pulse $\times$ mycorrhiza was also significant for several plant traits, again those related to below-ground performance (Table 1). Boswellia seedlings

Table 1 ANOVA table showing the effect of mycorrhiza and water pulse on plant traits of Boswellia seedlings

\begin{tabular}{|c|c|c|c|c|c|c|c|}
\hline \multirow[t]{2}{*}{ Parameters } & \multirow[t]{2}{*}{ Units } & \multicolumn{2}{|l|}{$\mathrm{AM}$} & \multicolumn{2}{|l|}{ Water } & \multicolumn{2}{|c|}{$\mathrm{AM} \times$ water } \\
\hline & & $F$ & $P$ & $F$ & $P$ & $F$ & $P$ \\
\hline Leaf number & Number & 36.341 & $0.000 *$ & 0.105 & 0.747 & 0.006 & 0.940 \\
\hline Leaf area & $\mathrm{cm}^{2}$ & 3.891 & 0.052 & 1.977 & 0.163 & 9.817 & $0.001 *$ \\
\hline Coarse root dry mass & $\mathrm{g}$ & 110.464 & $0.000 *$ & 9.342 & 0.003 & 31.221 & $0.000 *$ \\
\hline Root dry mass & $\mathrm{g}$ & 107.133 & $0.000 *$ & 9.404 & 0.003 & 31.084 & $0.000^{*}$ \\
\hline Plant dry mass & $\mathrm{g}$ & 98.902 & $0.000 *$ & 7.599 & 0.007 & 30.021 & $0.000 *$ \\
\hline Biomass increase & $\%$ & 45.520 & $0.000 *$ & 0.384 & 0.537 & 8.421 & 0.004 \\
\hline Plant relative growth rate & $\%$ month $^{-1}$ & 94.144 & $0.000 *$ & 6.200 & 0.014 & 27.247 & $0.000 *$ \\
\hline Root relative growth rate & $\%$ month $^{-1}$ & 101.055 & $0.000 *$ & 7.624 & 0.007 & 27.514 & $0.000^{*}$ \\
\hline Coarse root relative growth rate & $\%$ month $^{-1}$ & 104.123 & $0.000 *$ & 7.532 & 0.007 & 27.583 & $0.000 *$ \\
\hline Specific root length & $\mathrm{mm} \mathrm{g}^{-1}$ & 17.994 & $0.000 *$ & 1.531 & 0.218 & 0.473 & 0.493 \\
\hline Root length per plant mass & $\mathrm{mm} \mathrm{g}^{-1}$ & 17.113 & $0.000 *$ & 0.730 & 0.395 & 0.751 & 0.388 \\
\hline Shoot phosphorus & $\%$ & 13.527 & $0.000 *$ & 9.614 & 0.003 & 1.973 & 0.163 \\
\hline Root phosphorus & $\%$ & 13.888 & $0.000 *$ & 7.697 & 0.007 & 0.019 & 0.889 \\
\hline
\end{tabular}

A two-way ANOVA was used to test the effect of mycorrhiza, watering and their interaction but only presented for parameters with significant effect (the whole effect was presented as an electronic supplementary table). Except for gas exchange, all traits were measured and/or calculated after the harvest

* Significant after Bonferroni correction 
were mycorrhiza-responsive. Because drought response index was smaller than 1 in non-mycorrhizal seedlings but larger than 1 in mycorrhizal seedlings, mycorrhizal responsiveness was much higher after water pulsing than with continuous water supply (Fig. 1). For the three age classes, mycorrhizal responsiveness was around $300 \%$ for seedlings exposed to water-pulsing, whereas it was around $150 \%$ for seedlings with continuous water supply. Mycorrhizal responsiveness increased with the duration of the experiment. Both a larger leaf area (Table 1; Fig. 2a; significant interaction water pulse $\times$ mycorrhiza) and higher assimilation rate per unit leaf area (Table 2; Fig. 2c; water pulse, mycorrhiza and interaction water pulse $\times$ mycorrhiza all significant sources of variation) contributed to this increased plant dry mass. Higher assimilation rate per unit leaf area coincided with higher $\mathrm{P}$ mass fractions in mycorrhizal seedlings.

Boswellia seedlings allocated most carbon belowground, especially to the coarse root, regardless of treatment, and age. Coarse-root mass fraction was $83 \%$ for non-mycorrhizal seedlings and somewhat higher, $92 \%$ for mycorrhizal seedlings. The interaction water pulse $\times$ mycorrhiza was significant.

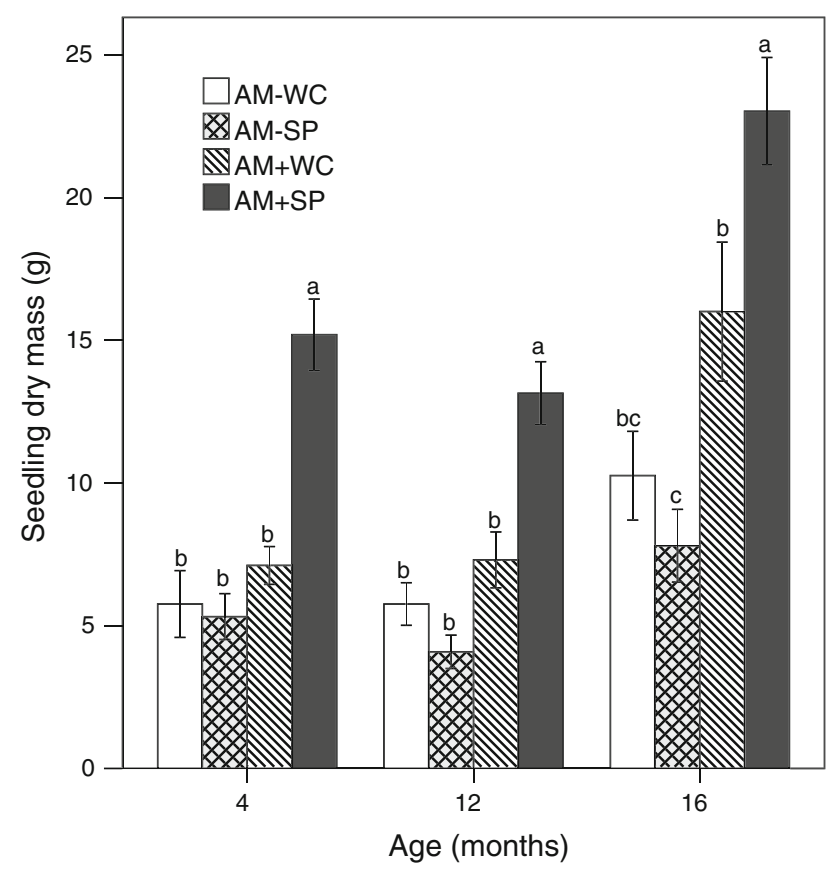

Fig. 1 The effects is presented of arbuscular mycorrhiza and water regime on seedling mass (mean $\pm 1 \mathrm{SE}$ ) of Boswellia. Arbuscular mycorrhizal treatment $(\mathrm{AM}+)$ is compared with a control without inoculation (AM-), and water pulse every 2 weeks (SP) during the wet seasons is compared with a control with regular water supply during the wet season (WC). Seedlings in the 12-month category die back aboveground during the 8-month dry period, as a consequence of which there were no differences in biomass between the 4- and 12month-old seedlings. Different letters (per age class) indicate significant differences between treatments $(P<0.05)$
Plant nutrients

Nutrient mass fractions in shoot and root were significantly affected by seedling age (for N, P, K), mycorrhiza (for P), but not by water pulse (online information 1). Phosphorus mass fractions in shoot and roots were significantly higher for AM seedlings. The interaction mycorrhiza $\times$ age was significant for shoot $\mathrm{N}$, and shoot and root $\mathrm{P}$ while the interaction age $\times$ water pulse was significant for root $\mathrm{N}$ and $\mathrm{K}$ (online information 1). Boswellia seedlings had significantly higher mass fractions of $\mathrm{N}$ and $\mathrm{K}$ in their roots than in the shoots $(P<0.001)$.

\section{AM colonization}

All control Boswellia seedlings at all harvests remained free of mycorrhiza. Water pulse was a significant source of variation for fractional colonization (Table 2). Average fractional colonization for the seedlings under continuous water supply was $64 \%$, compared to $89 \%$ for the seedlings that received a water pulse. Arbuscular, vesicular, and hyphal colonization and mycorrhizal root length were all significantly higher for seedlings in the waterpulse treatment than in the regular water treatment (Table 2).

\section{Gas exchange}

Seedling age, mycorrhiza, and water pulse were all significant sources of variation for stomatal conductance, whereas none of the interactions were significant (online resource 1). Assimilation and water use efficiency of the oldest seedlings were significantly affected by mycorrhiza, water pulse, and the interaction (Table 3). Transpiration rate was not affected by mycorrhiza or water pulse, but the interaction was highly significant. Mycorrhizal plants in the water-pulse treatment had significantly higher assimilation rates than the other treatments (Fig. 2c). Transpiration rates were significantly higher in non-mycorrhizal plants with regular water supply and in mycorrhizal plants under pulsed conditions than in the other treatments (Fig. 2b). Water use efficiency was higher for mycorrhizal than for non-mycorrhizal plants and higher for water-pulsed plants than for plants that received water regularly (Fig. 2d). Stomatal conductance was higher for mycorrhizal plants than for nonmycorrhizal plants and higher for regularly watered plants than for plants in the water-pulse treatment (Fig. 2f). Stomatal conductance and water use efficiency were not correlated. No significant differences were observed in relative water content and leaf water potential among treatments within the same age class (online resource 1). 

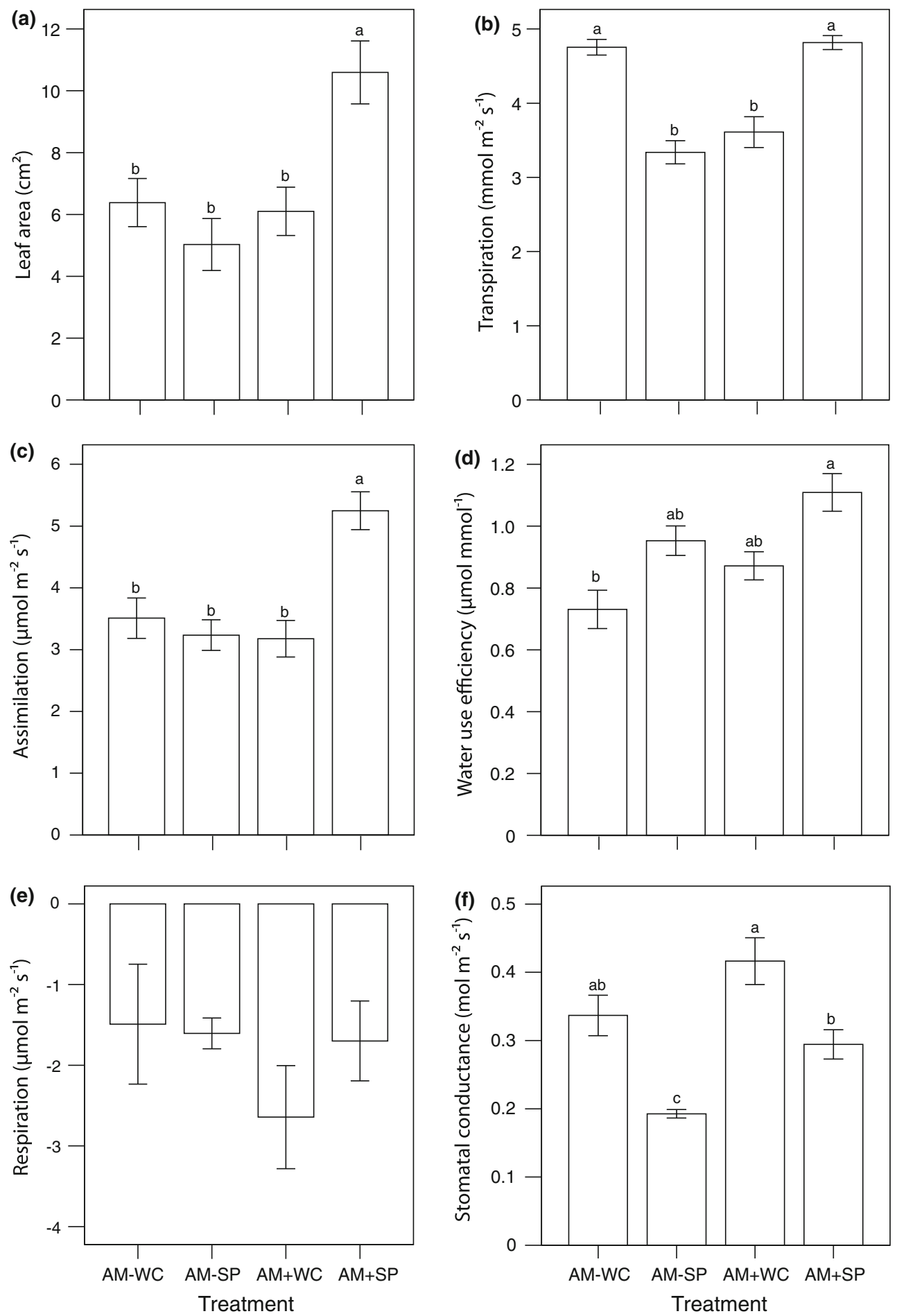

Fig. 2 The effects is presented of arbuscular mycorrhiza and water regime on gas exchange (mean $\pm 1 \mathrm{SE}$ ) of 16-month-old Boswellia seedlings. Arbuscular mycorrhizal treatment $(\mathrm{AM}+)$ is compared with a control without inoculation (AM-), and water pulse every 2 weeks

(SP) during the wet seasons is compared with a control with regular water supply during the wet season (WC). Different letters indicate significant differences between treatments $(P<0.05)$

\section{Discussion}

high mycorrhizal responsiveness of Boswellia, especially under conditions of water-pulsing, confirms the crucial role of the mycorrhizal symbiosis in these harsh environments.

We observed a positive effect of the mycorrhizal symbiosis The positive mycorrhizal effect is due to improved 
Table 2 Fractional mycorrhizal colonization and mycorrhizal root length (mean \pm SE) for inoculated seedlings of Boswellia

\begin{tabular}{|c|c|c|c|c|c|c|c|c|c|c|c|}
\hline \multirow{2}{*}{$\begin{array}{l}\text { Colonization } \\
\text { percentage }\end{array}$} & \multicolumn{5}{|l|}{ Age } & \multicolumn{4}{|l|}{ Water } & \multicolumn{2}{|c|}{ Age $\times$ water } \\
\hline & 4 & 12 & 16 & $F$ & $P$ & $\mathrm{WC}$ & SP & $F$ & $P$ & $F$ & $P$ \\
\hline $\begin{array}{l}\text { Arbuscular } \\
\text { colonization }\end{array}$ & $0.404 \pm 0.03$ & $0.464 \pm 0.03$ & $0.577 \pm 0.03$ & 1.953 & 0.151 & $0.344 \pm 0.02 b$ & $0.62 \pm 0.02 \mathrm{a}$ & 14.815 & 0.000 & 0.315 & 0.731 \\
\hline $\begin{array}{l}\text { Vesicular } \\
\quad \text { colonization }\end{array}$ & $0.631 \pm 0.03$ & $0.637 \pm 0.03$ & $0.657 \pm 0.03$ & 0.054 & 0.948 & $0.448 \pm 0.02 b$ & $0.814 \pm 0.02 \mathrm{a}$ & 29.148 & 0.000 & 4.795 & 0.012 \\
\hline Hyphal colonization & $0.649 \pm 0.04 b$ & $0.725 \pm 0.04 b$ & $0.915 \pm 0.04 \mathrm{a}$ & 7.443 & 0.001 & $0.641 \pm 0.03 b$ & $0.885 \pm 0.03 a$ & 15.596 & 0.000 & 0.094 & 0.911 \\
\hline $\begin{array}{l}\text { Mycorrhizal root } \\
\text { length }\end{array}$ & $13.091 \pm 1.333$ & $21.281 \pm 1.333$ & $32.35 \pm 1.333$ & 2.470 & 0.093 & $13.489 \pm 1.264 b$ & $32.137 \pm 1.333 \mathrm{a}$ & 6.790 & 0.012 & 0.957 & 0.390 \\
\hline
\end{tabular}

A two-way ANOVA is used to test for the effects of age and water and their interaction

Different letters indicate significant differences between treatments $(P<0.05)$

Table 3 Gas exchange (mean $\pm \mathrm{SE}$ ) in 16-month-old Boswellia seedlings

\begin{tabular}{|c|c|c|c|c|c|c|c|c|c|c|c|}
\hline \multirow[t]{2}{*}{ Traits } & \multirow[t]{2}{*}{ Units } & \multicolumn{4}{|l|}{ AM inoculation } & \multicolumn{4}{|l|}{ Water } & \multicolumn{2}{|c|}{$\mathrm{AM} \times$ water } \\
\hline & & $\mathrm{AM}-$ & $\mathrm{AM}+$ & $F$ & $P$ & WC & SP & $F$ & $P$ & $F$ & $P$ \\
\hline Assimilation & $\mu \mathrm{mol} \mathrm{C} \mathrm{m}{ }^{-2} \mathrm{~s}^{-1}$ & $2.88 \pm 1.057 \mathrm{~b}$ & $3.72 \pm 1.069 \mathrm{a}$ & 8.466 & 0.004 & $2.95 \pm 1.073$ & $3.66 \pm 1.049$ & 5.539 & 0.020 & 8.116 & 0.005 \\
\hline $\begin{array}{l}\text { Stomatal } \\
\quad \text { conductance }\end{array}$ & $\mathrm{mol} \mathrm{m}^{-2} \mathrm{~s}^{-1}$ & $0.254 \pm 0.017 b$ & $0.344 \pm 0.018 \mathrm{a}$ & 13.777 & 0.000 & $0.361 \pm 0.018 \mathrm{a}$ & $0.237 \pm 0.016 \mathrm{~b}$ & 25.929 & 0.000 & 0.684 & 0.409 \\
\hline Transpiration & $\mathrm{mmol} \mathrm{H}_{2} \mathrm{O} \mathrm{m}^{-2} \mathrm{~s}^{-1}$ & $4.046 \pm 0.093$ & $4.214 \pm 0.111$ & 1.345 & 0.248 & $4.182 \pm 0.120$ & $4.077 \pm 0.081$ & 0.519 & 0.472 & 82.019 & 0.000 \\
\hline Respiration & $\mu \mathrm{mol} \mathrm{C} \mathrm{m}{ }^{-2} \mathrm{~s}^{-1}$ & $-0.73 \pm 1.230$ & $-1.285 \pm 1.294$ & 2.837 & 0.097 & $-0.75 \pm 1.23$ & $-1.26 \pm 1.291$ & 2.490 & 0.120 & 4.074 & 0.048 \\
\hline $\begin{array}{l}\text { Water use } \\
\text { efficiency }\end{array}$ & $\mu \mathrm{mol} \mathrm{mmol}{ }^{-1}$ & $0.842 \pm 0.044 b$ & $0.990 \pm 0.053 a$ & 4.663 & 0.032 & $0.801 \pm 0.057 \mathrm{~b}$ & $1.031 \pm 0.039 \mathrm{a}$ & 11.193 & 0.001 & 7.380 & 0.000 \\
\hline
\end{tabular}

A two-way ANOVA is used to test for the effects of mycorrhiza and water and their interaction

Different letters indicate significant differences between treatments $(P<0.05)$

phosphorus nutrition, which was evident by the significantly higher P mass fractions in shoots and roots of mycorrhizal plants compared to non-mycorrhizal plants. The beneficial effect of the mycorrhizal symbiosis was much larger under irregular precipitation (or water-pulsed) conditions than regular precipitation (continuous water supply).

Irregular water supply had a negative effect in nonmycorrhizal Boswellia seedlings. However, water-pulsing improved performance of mycorrhizal seedlings compared to regular watering, and this effect became stronger over time. This contrast confirms the essential role of the mycorrhizal symbiosis in case of unpredictable water availability. Both leaf area and assimilation rate per unit leaf area were highest in that treatment combination. The AM symbiosis increased coarse root biomass resulting in more water storage (Roumet et al. 2006; Chidumayo and Frost 1996). Plants that store more water can maintain their stomata open, resulting in increased assimilation and (but to a lesser extent) increased transpiration rates (Fig. 2b, c). Mycorrhizal fungi in combination with water supply in pulses drove some of the major changes in leaf area, coarse root mass, and leaf photosynthesis in Boswellia seedlings, which positively influence growth (Daughtridge et al. 1986; Wright et al. 1998).

In conjunction with larger plant size and an improved phosphorus status of mycorrhizal plants, we noted an increase in assimilation (in combination with water-puls- ing), water use efficiency, and stomatal conductance (both independent of water pulsing; Fig. 2). An increase in stomatal conductance in mycorrhizal plants has been repeatedly observed. Such increases were noted both for comparisons of mycorrhizal and non-mycorrhizal plants of the same size and P status and for cases where mycorrhizal plants were significantly larger and with higher leaf nutrient mass fractions (Augé 2001). Subsequent studies have confirmed this pattern, while also showing the importance of plant functional type. Apparently, plant strategy (along the axis from a conservative to acquisitive strategy for both above-ground and below-ground resources; cf. Díaz et al. 2004) is a major determinant of the extent to which the mycorrhizal symbiosis affects stomatal conductance. Querejeta et al. (2003) observed that AM fungi enhanced stomatal conductance in the slow-growing Olea europaea ssp. sylvestris and hardly so in the fast-growing Rhamnus lycioides. In a subsequent study, Querejeta et al. (2007a) compared seedlings of the dryland shrubs Pistacia lentiscus and Retama sphaerocarpa, a leafless legume with photosynthesizing stems. Retama was less responsive to mycorrhizal inoculation than Pistacia and showed no increase in stomatal conductance (as assessed from the $\delta^{18} \mathrm{O}$ signal, a proxy for stomatal conductance). However, the mycorrhizal symbiosis can also lower stomatal conductance. Goicoechea et al. (2004) reported that drought induced a larger 
decline in stomatal conductance in the drought-avoiding, nitrogen-fixing Anthyllis cytisoides in the mycorrhizal condition than in the non-mycorrhizal condition. Drought also reduced photosynthesis more in mycorrhizal than in nonmycorrhizal plants, and leaf nutrient mass fractions were also lower in mycorrhizal plants at peak drought. The authors concluded that the mycorrhizal symbiosis still conferred drought resistance to this shrub, because mycorrhizal plants had higher rates of leaf shedding as a mechanism of adaptation to drought. Not only plant identity but also fungal identity could affect changes in stomatal conductance under drought. Querejeta et al. (2006) compared native, drought-adapted AM fungi with non-native strains and noted that the drought-adapted species more strongly increased stomatal conductance than non-native species. Larger increases in stomatal conductance in drought-adapted AM fungal species coincided with larger improvements in nutrient uptake. A major effect of AM fungal species provenance was also noted by Ruiz-Lozano and Azcon (1995) and Marulanda et al. (2006).

Increased stomatal conductance of mycorrhizal plants compared to non-mycorrhizal plants would normally translate into increased photosynthesis. However, this response was not observed when plants were adequately watered (WC). Instead, transpiration rates of mycorrhizal plants were significantly lower than those of non-mycorrhizal plants, and as a consequence the mycorrhizal symbiosis did improve water use efficiency. Under water-pulsed conditions (SP), increased stomatal conductance resulted in increased assimilation rates. Transpiration rates also increased, but the fractional increase was smaller. Consequently, water use efficiency was also higher for mycorrhizal plants compared to non-mycorrhizal plants under conditions of pulsed water availability.

Even though Boswellia seedlings always allocated most carbon to the coarse root system, mycorrhizal seedlings had more $\mathrm{C}$ allocated to the roots than non-mycorrhizal seedlings. The significantly higher amounts of carbon and nutrients allocated below-ground indicate that AM Boswellia seedlings store the resources acquired during the growing season in the roots when they die back as a resource conservation strategy. Considering the structure of the coarse root, it is likely that this organ also serves as a water storage organ from which mycorrhizal fungi might benefit under conditions of drought. Querejeta et al. (2007b) studied the effect of severe soil drying on the functioning of the mycorrhizal fungal network in an oak savanna in California. The authors concluded that the trees access water from groundwater, and that this water is exuded in the topsoil from which the mycorrhizal fungal mycelium subsequently benefits. In our greenhouse, the seedlings did not have access to additional water sources. However, storage of water in coarse roots and its provision to the AM fungi explain why mycorrhizal plants did have access to more water during an irregular precipitation regime. Moreover, mycorrhizal plants under water-pulsed conditions had significantly higher transpiration rates than those of plants provided with regular water. Provision of water to hyphae through the coarse roots also explains how mature trees maintain (and even increase) levels of mycorrhizal colonization during dry periods, as observed in our previous field study (Birhane et al. 2010).

A better water status of mycorrhizal seedlings compared to non-mycorrhizal seedlings may result in seedlings that are better able to capture resources during the next rainy season. After a period of 8 months of not watering, when seedlings had died back above-ground, an increase in atmospheric humidity resulted in renewed above-ground emergence of seedlings. Similar behavior to increased atmospheric humidity was observed in miombo trees (Chidumayo and Frost 1996). Seedling emergence, before the next round of watering started, was higher for mycorrhizal seedlings $(53 \%)$ compared to non-mycorrhizal seedlings $(37 \%)$, but the difference was not significant. Faster emergence expands the window of opportunity for Boswellia seedlings to further achieve a positive carbon and nutrient balance, and may ultimately shorten the period (of several years to decades) that the tree shows annual cycles of die-back, before it finally achieves the height growth that allows it to escape from grazing and fire.

\section{Conclusion}

The AM symbiosis changed plant growth, biomass (especially below-ground biomass), phosphorus mass fraction in leaves and roots, and photosynthetic performance of Boswellia seedlings. The strong interaction between mycorrhiza and the water-pulse treatment showed that mycorrhizal Boswellia actually benefits from irregular water supply during the short rainy season. Water-pulsing increased leaf area and phosphorus mass fractions in mycorrhizal seedlings, resulting in the highest assimilation rates. Even though transpiration rates were also increased, water use efficiency was highest in mycorrhizal seedlings in the irregular precipitation regime. The conservative acquisition strategy of Boswellia, where carbon and water acquired in the rainy season are stored in coarse roots, is beneficial in this harsh climate. By this strategy (waiting in the underground), seedlings disconnect carbon gain from nutrient gain, and store reserves below-ground until they are able to produce shoots that grow sufficiently high to escape the impacts of grazing and fire. A major question for further research is whether other trees than Boswellia in this habitat show this conservative acquisition strategy, or whether more acquisitive strategies also occur under such climates. 
A further question is how mycorrhiza and water availability affect competition between plants with different resource acquisition strategies. Such knowledge is essential for sustainable management of these economically and ecologically important species.

Acknowledgments We are grateful to the two anonymous referees for constructive comments on an earlier version of this manuscript. Emiru Birhane was granted study leave from Mekelle University, and was supported by a sandwich $\mathrm{PhD}$ grant from Wageningen University and research grants from NORAD II project and IFS (International Foundation for Science). The work for this study was supported by the Netherland Fellowship programme (NUFFIC) and NWO-WOTRO (Netherlands Organization for Scientific Research-Science for Global Development) through the integrated program FRAME (Frankincense, myrrh and gum arabic: sustainable use of dry woodlands resources in Ethiopia). We thank Azmera for following up the day to day activities of the greenhouse for 16 months. The experiment complies with the current laws of Ethiopia, where the experiment was performed.

Conflict of interest The authors declare they have no conflict of interest.

Open Access This article is distributed under the terms of the Creative Commons Attribution License which permits any use, distribution, and reproduction in any medium, provided the original author(s) and the source are credited.

\section{References}

Abiyu A, Bongers F, Eshete A, Gebrehiwot K, Kindu M, Lemenih M, Moges Y, Ogbazghi W, Sterck F (2010) Incense woodlands in Ethiopia and Eritrea: regeneration problems and restoration possibilities. In: Bongers F, Tennigkeit T (eds) Degraded forests in Eastern Africa: management and restoration. Earth Scan, London, pp 133-152

Anderson JM, Ingram JSI (eds) (1993) Tropical soil biology and fertility: a handbook of methods. CABI, Wallingford

Apple ME (2010) Aspects of mycorrhizae in desert plants. In: Ramawat KG (ed) Desert plants. Springer, Berlin, pp 121-134

Augé RM (2001) Water relations, drought, and vesicular-arbuscular mycorrhizal symbiosis. Mycorrhiza 11:3-42. doi:10.1007/ s005720100097

Augé RM (2004) Arbuscular mycorrhizae and soil/plant water relations. Can J Soil Sci 84:373-381

Bekele TA (2007) Useful trees and shrubs for Ethiopia: identification propagation and management for agricultural and pastoral communities. Regional Soil Conservation Unit/SIDA. English Press, Nairobi

Birhane E, Kuyper TW, Sterck FJ, Bongers F (2010) Arbuscular mycorrhizal associations in Boswellia papyrifera (frankincensetree) dominated dry deciduous woodlands of Northern Ethiopia. For Ecol Manag 260:2160-2169. doi:10.1016/j.foreco.2010.09. 010

Brundrett M, Bougher N, Dell B, Grove T, Malajczuk N (1996) Working with mycorrhiza in forestry and agriculture. ACIAR Monograph 32

Chesson P, Gebauer RLE, Schwinning S, Huntly N, Wiegand K, Ernest MSK, Sher A, Novoplansky A, Weltzin JF (2004) Resource pulses, species interactions, and diversity maintenance in arid and semi-arid environments. Oecologia 141:236-253. doi:10.1007/s00442-004-1551-1
Chiariello NR, Mooney HA, Williams K (1989) Growth, carbon allocation and cost of plant tissues. In: Pearcy RW, Ehleringer J, Mooney HA, Rundel PW (eds) Plant physiological ecology: field methods and instrumentation. Chapman and Hall, London, pp 327-365

Chidumayo E, Frost P (1996) Population biology of miombo trees. In: Campbell BM (ed) The miombo in transition: woodlands and welfare in Africa. Centre for International Forestry Research, Bogor, pp 59-71

Collins SL, Sinsabaugh RL, Crenshaw C, Green L, Porras-Alfaro A, Stursova M, Zeglin LH (2008) Pulse dynamics and microbial processes in arid land ecosystems. J Ecol 96:413-420. doi:10.1111/ j.1365-2745.2008.01362.x

Daughtridge AT, Pallardy SG, Garett HG, Sander IL (1986) Growth analysis of mycorrhizal and nonmycorrhizal black oak (Quercus velutina Lam.) seedlings. New Phytol 103:473-480

Díaz S, Hodgson JG, Thompson K, Cabido M, Cornelissen JHC, Jalili A, Montserrat-Martí G, Grime JP, Zarrinkamar F, Asri Y, Band SR, Basconcelo S, Castro-Díez P, Funes G, Hamzehee B, Khoshnevi M, Pérez-Harguindeguy N, Pérez-Rontomé MC, Shirvany FA, Vendramini F, Yazdani S, Abbas-Azimi R, Bogaard A, Boustani S, Charles M, Dehghan M, de Torres-Espuny L, Falczuk V, Guerrero-Campo J, Hynd A, Jones G, Kowsary E, Kazemi-Saeed F, Maestro-Martínez M, Romo-Díez A, Shaw S, Siavash B, Villar-Salvador P, Zak M (2004) The plant traits that drive ecosystems: evidence from three continents. J Veg Sci 15:295-304. doi:10.1111/j.1654-1103.2004.tb02266.x

Gebrehiwot K, Muys B, Haile M, Mitloehner R (2005) The use of plant water relations to characterize tree species and sites in the drylands of Northern Ethiopia. J Arid Environ 60:581-592. doi:10.1016/j.jaridenv.2004.07.009

Gebrekirstos A, Teketay D, Fetene M, Mithloehner R (2006) Adaptation of five co-occurring tree and shrub species to water stress and its implication in restoration of degraded lands. For Ecol Manag 229:259-267. doi:10.1016/j.foreco.2006.04.029

Gindaba J, Rozanov A, Ngash L (2004) Response of seedlings of two Eucalyptus and three deciduous tree species from Ethiopia to severe water stress. For Ecol Manag 201:119-129. doi:10.1016/ j.foreco.2004.07.009

Gindaba J, Rozanov A, Negash L (2005) Photosynthetic gas exchange, growth, and biomass allocation of two Eucalyptus and three indigenous tree species of Ethiopia under moisture deficit. For Ecol Manag 205:127-138. doi:10.1016/j.foreco.2004.10.056

Giovannetti M, Mosse B (1980) An evaluation of techniques for measuring vesicular arbuscular mycorrhizal infection. New Phytol 84:489-500

Goicoechea N, Merino S, Sánchez-Díaz M (2004) Contributions of arbuscular mycorrhizal fungi (AMF) to the adaptations exhibited by the deciduous shrub Anthyllis cytisoides under water deficit. Physiol Plant 122:453-464. doi:10.1111/j.1399-3054.2004. 00421.x

Hunt R (1990) Basic growth analysis. Unwin Hyman, London

Kaschuk G, Kuyper TW, Leffelaar PA, Hungria M, Giller KE (2009) Are the rates of photosynthesis stimulated by the carbon sink strength of rhizobial and arbuscular mycorrhizal symbioses? Soil Biol Biochem 41:1233-1244. doi:10.1016/j.soilbio.2009.03.005

Kaya C, Higgs D, Kirnak H, Tas I (2003) Mycorrhizal colonization improves fruit yield and water use efficiency in watermelon (Citrullus lanatus Thunb.) grown under well-watered and water stressed conditions. Plant Soil 253:287-292. doi:10.1023/ A: 1024843419670

Koide RT, Robichaux RH, Morse SR, Smith CM (1989) Plant water status, hydraulic resistance and capacitance. In: Pearcy RW, Ehleringer J, Mooney HA, Rundel PW (eds) Plant physiological ecology: field methods and instrumentation. Chapman and Hall, London, pp 161-183 
Lambers HF, Chapin S, Pons TL (2008) Plant physiological ecology. Springer, New York

Lapointe L (2001) How phenology influences physiology in deciduous forest spring ephemerals. Physiol Plant 113:151-157. doi:10.1034/ j.1399-3054.2001.1130201.x

Lapointe L, Molard J (1997) Costs and benefits of mycorrhizal infection in a spring ephemeral, Erythronium americanum. New Phytol 135:491-500. doi:10.1046/j.1469-8137.1997.00672.x

Marulanda A, Barea JM, Azcon R (2006) An indigenous drought-tolerant strain of Glomus intraradices associated with a native bacterium improves water transport and root development in Retama sphaerocarpa. Microb Ecol 52:670-678. doi:10.1007/s00248006-9078-0

Ogbazgi W, Rijkers T, Wessel M, Bongers F (2006) Distribution of the frankincense Boswellia papyrifera tree in Eritrea: the role of environment and land use. J Biogeogr 33:524-535. doi:10.1111/ j.1365-2699.2005.01407.x

Querejeta JI, Barea JM, Allen MF, Caravaca F, Roldán A (2003) Differential response of $\delta^{13} \mathrm{C}$ and water use efficiency to arbuscular mycorrhizal infection in two aridland woody plant species. Oecologia 135:510-515. doi:10.1007/s00442-003-1209-4

Querejeta JI, Allen MF, Caravaca F, Roldán A (2006) Differential modulation of host plant ${ }^{13} \mathrm{C}$ and ${ }^{18} \mathrm{O}$ by native and non-native arbuscular mycorrhizal fungi in a semiarid environment. New Phytol 169:379-387. doi:10.1111/j.1469-8137.2005.01599.x

Querejeta JI, Allen MF, Alguacil MM, Roldán A (2007a) Plant isotopic composition provides insight into mechanisms underlying growth stimulation by AM fungi in a semiarid environment. Funct Plant Biol 34:683-691. doi:10.1071/FP07061

Querejeta JI, Egerton-Warburton LM, Allen MF (2007b) Hydraulic lift may buffer rhizosphere hyphae against the negative effects of severe soil drying in a California oak savanna. Soil Biol Biochem 39:409-417. doi:10.1016/j.soilbio.2006.08.008
Roumet C, Urcelay C, Diaz D (2006) Suites of root traits differ between annual and perennial species growing in the field. New Phytol 170:357-368

Ruiz-Lozano JM, Aroca R (2010) Host response to osmotic stresses: stomatal behaviour and water use efficiency of arbuscular mycorrhizal plants. In: Koltai H, Kapulnik Y (eds) Arbuscular mycorrhizas: physiology and function. Springer, Berlin, pp 239-256. doi:10.1007/978-90-481-9489-6_11

Ruiz-Lozano JM, Azcon R (1995) Hyphal contribution to water uptake in mycorrhizal plants as affected by the fungal species and water status. Physiol Plant 95:472-478. doi:10.1111/j.1399-3054.1995. tb00865.x

Scholander PF, Hammel HT, Bradstreet ED, Hemmingsen EA (1965) Sap pressure in vascular plants. Science 148:339-346. doi:10.1126/ science.148.3668.339

Schwinning S, Ehleringer JR (2001) Water use trade-offs and optimal adaptations to pulse-driven arid ecosystems. J Ecol 89:464-480. doi:10.1046/j.1365-2745.2001.00576.x

Schwinning S, Sala OE (2004) Hierarchy of responses to resource pulses in arid and semi-arid ecosystems. Oecologia 141:211-220. doi:10.1007/s00442-004-1520-8

Smith SE, Read DJ (2008) Mycorrhizal symbiosis. Academic, London

Smith SE, Facelli E, Pope S, Smith FA (2010) Plant performance in stressful environments: interpreting new and established knowledge of the roles of arbuscular mycorrhizas. Plant Soil 326:3-20. doi:10.1007/s11104-009-9981-5

Tennant D (1975) A test of modified line intersect method of estimating root length. J Ecol 63:995-1001

Wright DP, Scholes JD, Read DJ (1998) Effects of mycorrhizal colonization on photosynthesis and biomass production of Trifolium repens L. Plant Cell Environ 21:209-216. doi:10.1046/j.13653040.1998.00280.x 